\title{
A Study to Measure the Health Awareness of Polycystic Ovarian Syndrome in Saudi Arabia
}

\author{
Amal Alsinan ${ }^{1} \&$ Amani Ali Shaman ${ }^{2}$ \\ ${ }^{1}$ Medical Intern, Collage of Medicine, King Saud University, Riyadh, Saudi Arabia \\ ${ }^{2}$ Faculty of Medicine, University of Tabuk, Tabuk, Saudi Arabia \\ Correspondence: Dr. Amani Ali Shaman, Faculty of Medicine, University of Tabuk, Tabuk, Saudi Arabia.
}

\author{
Received: May 1, 2017 Accepted: June 5, 2017 Online Published: June 15, 2017 \\ doi:10.5539/gjhs.v9n8p130 \\ URL: https://doi.org/10.5539/gjhs.v9n8p130
}

\begin{abstract}
Background Study: There are various health disorders among women which might lead to various healthcare complications. In such cases, lack of awareness is one of the primary reasons for prolonged identification or poor disease self-management. Additionally, the freeness or comfort in discussing or gaining information can be a major limitation in managing such diseases. Polycystic Ovarian Syndrome (PCOS) is one such disorder among the women which can occur at reproductive age, and may cause infertility. The occurrence of disease at such a young age could lead to stress among the patients, and it also has major complications which can affect the health and lifestyles of the people diagnosed with PCOS. Therefore, it is very essential to increase the awareness about the disease and its self-management practices among the women.
\end{abstract}

Study Aim: The purpose of this study is to identify the level of awareness about PCOS among the Saudi women.

Study Design: An online survey questionnaire is used for collecting the knowledge levels of Saudi women with PCOS, in the aspects of physiology of female reproductive systems, knowledge of pathophysiology of PCOS, complications associated with PCOS, and self-management techniques.

Results: A minimal awareness about signs, symptoms, complications and self-management approaches of PCOS was observed in more than $60 \%$ of the motivated sample population.

Conclusion: It is observed and suggested that the perception of long-term metabolic effects of PCOS on the health of affected individual needs to be optimized. Effective methods for increasing awareness using internet and communication technologies should be developed and promoted among the women.

Keywords: health awareness, Polycystic Ovarian Syndrome, Saudi Arabia

\section{Introduction}

Polycystic ovarian syndrome is an endocrine system disorder with a collection of symptoms that are found as a result of a broad- spectrum hormonal disturbance. It is considered as one of the most common endocrine disorder in women at their reproductive age and a leading cause for infertility (Sedighi et al., 2014). The etiology of the disease is still unknown, but considerable evidence suggests that it is a combination of reproductive and metabolic abnormalities, which lead to hormonal disturbance in the form of high androgen and estrogen levels. This hormonal disturbance associated with loss of normal hormonal feedback results in steady state level of LH and low progesterone level. PCOS commonly manifests during adolescence, and it's primarily characterized by ovulatory dysfunction and hyperandrogenism. Moreover, PCOS could lead to numerous complications that may heavily affect woman's health and the quality of life (Thornton, Von Wald, \& Hansen, 2015). The most distinguishable symptoms are accounted to excess androgen production, resulting in anovulation, hirsutism, and acne. According to the new Rotterdam criteria formulated by the European Society for Human Reproduction and Embryology and the American Society for Reproductive Medicine, a minimum of two out of three criteria have to be met in order to be fit for the diagnosis of PCOS. These criteria include anovulation, androgen excess and polycystic ovarian morphology in ultrasound assessment (Broekmans et al., 2006). Women with PCOS also experience a diversity of symptoms/complications involving different systems, such as, gynecological (menses disorders, failure to ovulate, late menopause, endometrial cancer and infertility), metabolic (insulin resistance, diabetes type 2, dyslipidemia), cardiac (hypertension, and cardiovascular diseases), physical (central obesity, acne, hirsutism, hair loss and baldness), and psychological (depression, stress and anxiety)(Moran, Gibson-Helm, Teede, \& Deeks, 2010). 
Although, to date, the clinicians are more focused on the management of specific symptoms or disorders linked to PCOS, yet the major concern regarding the risk of possible complications, their occurrence, and confronting them to the patients remain unfocused. Evidence has suggested that approximately $25 \%$ to $30 \%$ of women with PCOS will show impaired glucose tolerance by the age of 30 and $8 \%$ of affected women will develop type 2 diabetes annually (Broekmans et al., 2006). Chronic anovulation which consist of unopposed estrogens secretion is known to predispose women to endometrial cancer and emerging evidence associates PCOS with ovarian and breast cancers (Stankiewicz \& Norman, 2006).

Considering the symptoms, the chronic course, and the complications of the disease, we as physicians and health care providers must acknowledge the great affect it has on the patients; physically, psychologically and socially. In addition, it is very important to address the patients concerns and meet their information needs, as a perception of insufficient information proved to be having a negative effect on the quality of life. Studies reported that sharing personal experiences and interacting with others, and having an easy accessibility to information and counsels had a positive effect on improving the quality of life; and feeling well informed enhances the sense of confidence and self-esteem (Memish et al., 2014). Even though there is a huge difference among the available sources of literature regarding the awareness process and methods, a number of studies do encourage and support the act of raising awareness. It was found that the process of increasing awareness had a positive association with decreasing depression and in improving the patients understanding of the disease, its course and its treatment, resulting in a healthier lifestyle and a more optimistic attitude. However the data on PCOS awareness among women in Saudi Arabia (KSA) is limited. Therefore in this study would focus on investigating the women's awareness and knowledge about the PCOS in Saudi society.

\section{Methodology}

\subsection{Study Setting and Participants}

In order to explore the awareness of polycystic ovarian syndrome in Saudi Arabia (KSA), a preliminary study on the current awareness of polycystic ovarian syndrome was carried out in KSA. The study was carried out through a follow up questionnaire designed to understand and identify the awareness of polycystic ovarian syndrome in Saudi society. A survey questionnaire designed by Colwell et al. was adopted in this study to measure the patients' knowledge regarding PCOS (Colwell, Lujan, Lawson, Pierson, \& Chizen, 2010). The questionnaire was designed and published online using Google forms. The women diagnosed with PCOS or those who feel that they have symptoms associated with PCOS were invited to share their opinions using an online survey link.

\subsection{Research Tools}

\subsubsection{Study Survey}

The questionnaire was designed to identify and analyse the PCOS patients' knowledge about the disease. A total of 21 multiple choice questions were designed with three answers including 'agree', 'disagree', and 'I do not know' to choose from. The questionnaire has been used and validated in a previous study conducted by Colwell et al. (Colwell et al., 2010). The questionnaire was classified into two sections, which include: the basic information of the participants, and the PCOS knowledge questionnaire. Furthermore, the questionnaire was translated into Arabic along with English version of each question, so that participants can easily understand. A sample snapshot of the online questionnaire structure is shown in Figure 1. 


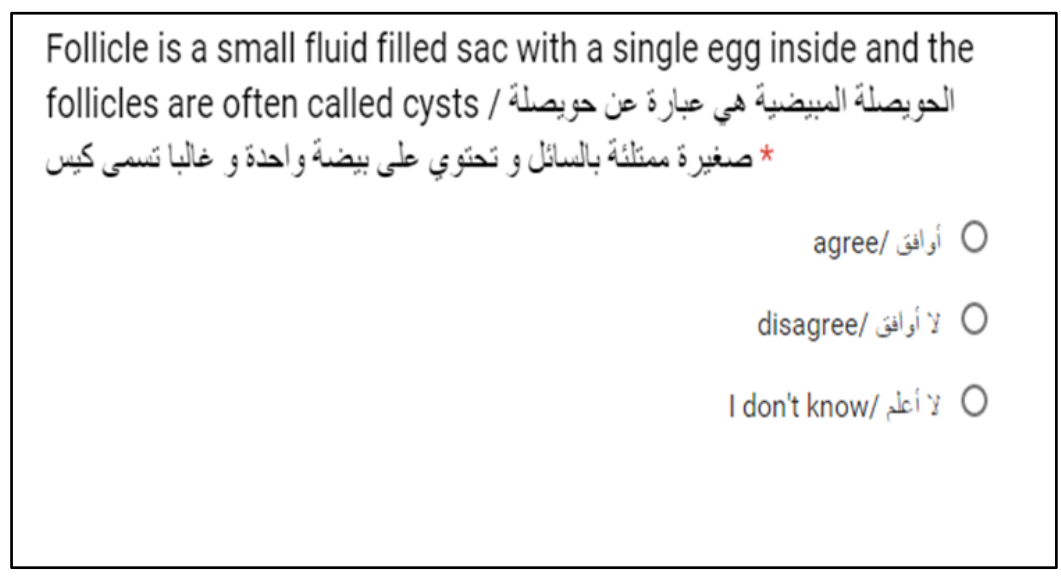

Figure 1. snapshot of the used online questionnaire in Arabic version

The questionnaire was published online using Google forms. The participants were briefed about the purpose of the study, and assured confidentiality and privacy about their responses in survey and personal information. A short description of the study is given in the first page of the questionnaire, including a summary of the significance of the research along with an assurance note that the information gathered through the survey would be used for research purposes only. The study has been approved by King Saudi University with reference number E-16-1812. The questionnaire was distributed from 01/03/2016 to 01/05/2016.

\section{Results}

Table 1 presents the demographic data of the Saudi women participated in the study. A total sample of (674) from different cities in Saudi Arabia was achieved in this survey. As shown in the Table 1, most of participants were young, and belong to the age group between 18 and 38 years, representing the two thirds of the sample population (73.5\%). Considering the education levels of the participants, $71.1 \%$ of the total participants were at college level, followed by high school group (16.6\%), and higher education (12.3\%).

Table 1. The demographic data

\begin{tabular}{llll}
\hline General characteristics & & & \\
\hline \multirow{3}{*}{ Age } & $18-24$ & 168 & $24.9 \%$ \\
& $25-31$ & 163 & $24.3 \%$ \\
& $32-38$ & 163 & $24.3 \%$ \\
& $39-45$ & 105 & $15.6 \%$ \\
\multirow{3}{*}{ Education level } & Above 45 & 75 & $11.1 \%$ \\
& High school & 112 & $16.6 \%$ \\
& College & 479 & $71.1 \%$ \\
\hline
\end{tabular}


Table 2. Basic knowledge about the physiology of female reproductive system of participants

\begin{tabular}{|c|c|c|c|}
\hline $\begin{array}{l}\text { الحويصلة المبيضية هي عبارة عن حويصلة صغيرة ممنلئة بالسائل و تحتوي على بيضة واحدة و غالبا تسمى كيس } \\
\text { Follicle is a small fluid filled sac with a single egg inside and the follicles are often } \\
\text { called cysts }\end{array}$ & $\begin{array}{l}320 \\
(47.5 \%)\end{array}$ & $\begin{array}{l}69 \\
(10.2 \%)\end{array}$ & $\begin{array}{l}285 \\
(42.3 \%)\end{array}$ \\
\hline $\begin{array}{l}\text { زيادة التبييض يحسن الخصوبة } \\
\text { Ovulating more frequently will improve my fertility }\end{array}$ & $\begin{array}{l}311 \\
(46.1 \%)\end{array}$ & $\begin{array}{l}216 \\
(32 \%)\end{array}$ & $\begin{array}{l}147 \\
(21.8 \%)\end{array}$ \\
\hline 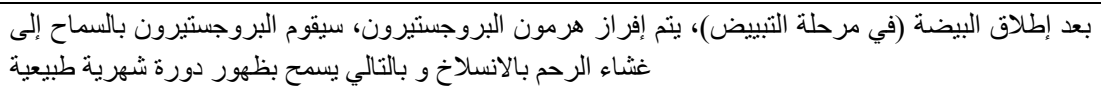 & $\begin{array}{l}426 \\
(63.2 \%)\end{array}$ & $\begin{array}{l}69 \\
(10.2 \%)\end{array}$ & $\begin{array}{l}179 \\
(26.6 \%)\end{array}$ \\
\hline
\end{tabular}

After egg release (ovulation), the hormone progesterone is released; progesterone would allow my uterine lining to shed and allow me to have a normal menstrual period

\begin{tabular}{|c|c|c|c|}
\hline الزيادة الثهرية في نسبة هرمون البروجستيرون و بالتالي في & & & \\
\hline $\begin{array}{l}\text { الدورة الثهرية، تؤدي إلى تقليل الفرصة بالإصابة بسرطان الرحم } \\
\text { Having monthly increases in progesterone, and therefore menstrual periods, would } \\
\text { decrease my risk for cancer of the uterus }\end{array}$ & $\begin{array}{l}184 \\
(27.3 \%)\end{array}$ & $\begin{array}{l}119 \\
(17.7 \%)\end{array}$ & $\begin{array}{l}371 \\
(55 \%)\end{array}$ \\
\hline $\begin{array}{l}\text { كمية الدهون في الجسم تأثر على كمية هرمون التيستوستيرون الحر في الجسم } \\
\text { The amount of fat in the body affects the amount of free testosterone in my body }\end{array}$ & $\begin{array}{l}383 \\
(56.8 \%)\end{array}$ & $23(3.4 \%)$ & $\begin{array}{l}268 \\
(39.8 \%)\end{array}$ \\
\hline $\begin{array}{l}\text { الإنسولين يباعد البويضة بإفراز هرمونات ذكرية أكثر } \\
\text { Insulin helps the ovary to make more male hormone }\end{array}$ & $\begin{array}{l}76 \\
(11.3 \%)\end{array}$ & $\begin{array}{l}146 \\
(21.7 \%)\end{array}$ & $\begin{array}{l}452 \\
(67.1 \%)\end{array}$ \\
\hline
\end{tabular}

Table 3. Participants' knowledge of pathophysiology of PCOS

\begin{tabular}{|c|c|c|c|}
\hline $\begin{array}{l}\text { تكيس المبايض يحتوي على حويصلات أكثر من البويضة الطبيعية } \\
\text { Polycystic ovaries contain more visible follicles than the average ovary }\end{array}$ & $\begin{array}{l}351 \\
(52.1 \%)\end{array}$ & $\begin{array}{l}50 \\
(7.4 \%)\end{array}$ & $\begin{array}{l}273 \\
(40.5 \%)\end{array}$ \\
\hline $\begin{array}{l}\text { تكيس المبايض يمر في فترة تبيض أقل من البويضة الطبيعية } \\
\text { Polycystic ovaries tend to ovulate less frequently than the average ovary. }\end{array}$ & $\begin{array}{l}253 \\
(37.5 \%)\end{array}$ & $\begin{array}{l}82 \\
(12.2 \%)\end{array}$ & $\begin{array}{l}339 \\
(50.3 \%)\end{array}$ \\
\hline $\begin{array}{l}\text { تكيس المبايض يقوم بإفراز هرمونات ذكرية، مثل (تيستوستيرون) أكثر من البويضة الطبيعية } \\
\text { Polycystic ovaries tend to make more male hormone like (testosterone) than the average } \\
\text { ovary }\end{array}$ & $\begin{array}{l}256 \\
(38 \%)\end{array}$ & $\begin{array}{l}66 \\
(9.8 \%)\end{array}$ & $\begin{array}{l}352 \\
(52.2 \%)\end{array}$ \\
\hline  & $\begin{array}{l}505 \\
(74.9 \%)\end{array}$ & $\begin{array}{l}18 \\
(2.7 \%)\end{array}$ & $\begin{array}{l}151 \\
(22.4 \%)\end{array}$ \\
\hline $\begin{array}{l}\text { نسبة الإنسولين العالية شائع في النساء ذوات تكبس المبايض } \\
\text { High insulin levels are common in women with }\end{array}$ & $\begin{array}{l}149 \\
(22.1 \%)\end{array}$ & $\begin{array}{l}72 \\
(10.7 \%)\end{array}$ & $\begin{array}{l}453 \\
(67.2 \%)\end{array}$ \\
\hline
\end{tabular}


Table 4. Knowledge of complications with PCOS

\begin{tabular}{|c|c|c|c|}
\hline نسبة الإنسولين العالية تضع الإنسان في خطورة الإصابة بمرض السكري & $\begin{array}{l}379 \\
(56.2 \%)\end{array}$ & $\begin{array}{l}106 \\
(15.7 \%)\end{array}$ & $\begin{array}{l}189 \\
(28 \%)\end{array}$ \\
\hline 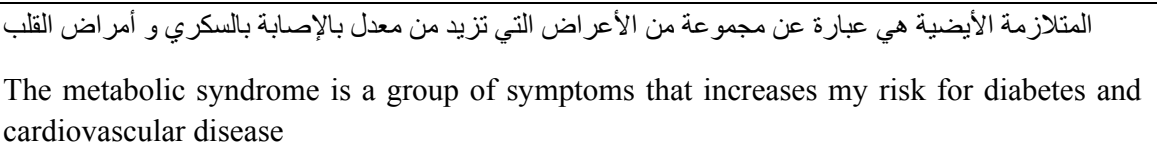 & $\begin{array}{l}465 \\
(69 \%)\end{array}$ & $\begin{array}{l}38 \\
(5.6 \%)\end{array}$ & $\begin{array}{l}171 \\
(25.4 \%)\end{array}$ \\
\hline $\begin{array}{l}\text { المتلازمة الأيضية شائعة في النساء ذوات تكييس المبايض } \\
\text { Metabolic syndrome is common in women with PCOS }\end{array}$ & $\begin{array}{l}188 \\
(27.9 \%)\end{array}$ & $\begin{array}{l}26 \\
(3.9 \%)\end{array}$ & $\begin{array}{l}460 \\
(68.2)\end{array}$ \\
\hline
\end{tabular}

Table 5. Knowledge of PCOS management

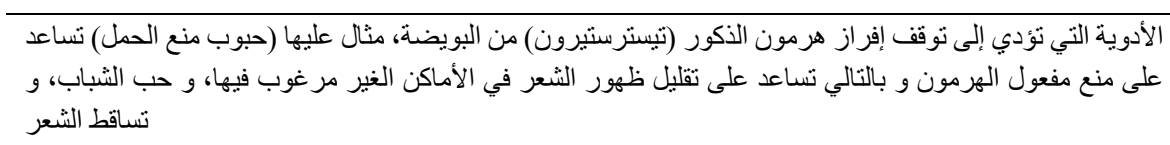

Medications that stop the production of male hormone by the ovary (like hormonal $320 \quad 100 \quad 254$ contraception) or block the effects of male hormone would help with unwanted hair growth, $(47.5 \%) \quad(14.8 \%)$ acne, and alopecia

\begin{tabular}{|c|c|c|c|}
\hline $\begin{array}{l}\text { تقليل نسبة الإنسولين تساعد على تقليل نسبة هرمون التيستوستيرون الحر، و أيضا تساعد على تقليل الوزن و تشاعد في التبيض } \\
\text { Lowering insulin levels may help decrease free testosterone, help with weight loss and help } \\
\text { trigger ovulation }\end{array}$ & $\begin{array}{l}229 \\
(34 \%)\end{array}$ & $\begin{array}{l}61 \\
(9.1 \%)\end{array}$ & $\begin{array}{l}384 \\
(57 \%)\end{array}$ \\
\hline $\begin{array}{l}\text { يمكن تقليل نسبة الإنسولين بالقيام بالرياضة و تغيير نظام التغذية } \\
\text { Insulin levels can be lowered by exercise and by certain changes in diet }\end{array}$ & $\begin{array}{l}519 \\
(77 \%)\end{array}$ & $34(5 \%)$ & $\begin{array}{l}121 \\
(18 \%)\end{array}$ \\
\hline $\begin{array}{l}\text { يمكن تقليل نسبة الإنسولين بإستخدام أدوية تجعل الجسم أكثر حساسية للإنسولين، مثل (المتفورمين) } \\
\text { Insulin levels can be lowered by medications that make the body more sensitive to insulin, } \\
\text { like metformin }\end{array}$ & $\begin{array}{l}193 \\
(28.6 \%)\end{array}$ & $\begin{array}{l}46 \\
(6.8 \%)\end{array}$ & $\begin{array}{l}435 \\
(64.5 \%)\end{array}$ \\
\hline $\begin{array}{l}\text { زيادة العضلات في الجسم تزيد معدل الأيض، معدل الأيض هي قدرة الجسم على حرق السعرات الحرارية } \\
\text { Increasing the amount of muscle in my body will increase my body’s metabolic rate, that is } \\
\text { my body’s ability to burn calories }\end{array}$ & $\begin{array}{l}420 \\
(62.3 \%)\end{array}$ & $\begin{array}{l}69 \\
(10.2 \%)\end{array}$ & $\begin{array}{l}185 \\
(27.4 \%)\end{array}$ \\
\hline $\begin{array}{l}\text { الرياضة و نظام غذائي صحي و تقليل الوزن بقلل معدل الإصابة بمتلازمة الأيضية } \\
\text { Exercise, healthy dieting and weight loss can decrease the risk of having metabolic } \\
\text { syndrome }\end{array}$ & $\begin{array}{l}490 \\
(72.7 \%)\end{array}$ & $9(1.3 \%)$ & $\begin{array}{l}175 \\
(26 \%)\end{array}$ \\
\hline $\begin{array}{l}\text { المعلومات أعلاه كافية لثرح مرض تكبس المبايض و تأثيره على الصحة } \\
\text { Enough about PCOS to explain what it is, and how it affects my health }\end{array}$ & $\begin{array}{l}266 \\
(39.5 \%)\end{array}$ & $\begin{array}{l}208 \\
(30.9 \%)\end{array}$ & $\begin{array}{l}200 \\
(29.7 \%)\end{array}$ \\
\hline
\end{tabular}


The basic knowledge of the participants' regarding the physiology of the female reproductive system is assessed using the questions presented in Table 2. From the results, it can be understood that the basic physiological knowledge of the participants is considerably low. Knowledge of physiology of follicle development was unknown to $53.5 \%$ of the participants; and the importance hormonal changes in progesterone occurs during menstrual cycle to protect endometrium from endometrial cancer was unknown to $70.7 \%$ of participants. Furthermore, the knowledge about ovulations (regular ovulations improving fertility rate) was unknown to $53.9 \%$ of participants. The knowledge about the effects of insulin on follicles and how hyperinsulinemia can drive the follicles to produce more androgens was unknown to $88.8 \%$ of the participants. However, the knowledge about production of progesterone after ovulation and its importance to have a regular period was known to $63.2 \%$ of the participants. Also, the knowledge about obesity and their effects on free testosterone level was known to $56.8 \%$ of the participants.

The participants' knowledge of pathophysiology of the disease was assessed using the questions presented in Table 3. Only $52.1 \%$ of the participants knew that polycystic ovaries would contain more visible follicles than the average ovary. However, the knowledge about association of disease with less ovulation which can affect their fertility was unknown to $62.5 \%$ of the participants; and the possibility of increase in the production of androgens in Patients diagnosed with PCOS was unknown to $62 \%$ of the participants. The knowledge of Hyperinsulinemia associated with PCOS, another important information was unknown to approximately two thirds (77.9\%) of the participants.

The participants' knowledge about PCOS complications was assessed using questions presented in Table 4. The knowledge about metabolic syndrome and high level of insulin can be associated with increased risk of developing diabetes millets and cardiac disease was known to $69 \%$ and $56.2 \%$ of participants respectively. But, $72.1 \%$ of the participants didn't know that metabolic syndrome is common in women diagnosed with PCOS.

The participants' knowledge about the management of PCOS and its general related information was assessed using the questions presented in Table 5. The information about the importance of exercise, healthy diet; and regular exercise can decrease insulin level and risk of metabolic syndrome was known to almost two third of participants $(77 \%$ and $72.2 \%)$. The knowledge about pharmacological treatments that can address some of the complications associated with PCOS, such as oral contraception and metformin was unknown to the majority of the participants.

\section{Discussion and Conclusion}

Polycystic ovarian syndrome is a common endocrine disorder affecting women at reproductive age. However, the prevalence of PCOS varies between different age groups depending on studied population (Naderpoor et al., 2015). It is a hyper-androgenic disorder associated with chronic oligo-anovulation and polycystic ovarian morphology (Pasquali \& Gambineri, 2015). PCOS can lead to various complications among women, including reproductive (infertility, miscarriage and pregnancy complications), metabolic (obesity, insulin resistance, prediabetes, type 2 diabetes DM2), and Psychological (anxiety, depression) health aspects (H. Teede, Deeks, \& Moran, 2010). First line of self-management of women diagnosed with PCOS is life style modifications, generally through healthy diet and increased physical activity to prevent weight gain (H. J. Teede et al., 2011). Usually many women remain undiagnosed for long time and they seek medical assistance only when they fail to conceive from mono-anovulation symptoms of PCOS (Norman, Wu, \& Stankiewicz, 2004). Considerable stress and trauma can be observed among the patients diagnosed with PCOS (Kitzinger \& Willmott, 2002). Women with PCOS have a great need for information to manage and limit its impact on their health and lifestyle (Lobo, 2001). Source of information can include advice from physicians; books; PCOS support group; and information available on Internet. Various studies have indicated that women with PCOS did not have positive experience with their doctors regarding initial information about the disease given by the doctor. Furthermore, some women were not satisfied with information provided by Physician, and felt that they were more informed about PCOS than the doctors (Avery \& Braunack-Mayer, 2007; Kitzinger \& Willmott, 2002). Internet is considered as the best source to obtain information about the disease, as it ensures privacy, sense of control, and up-to-date information at their fingertips (Avery \& Braunack-Mayer, 2007). However, the major limitation in this aspect is that there is no control over quality and credibility of information exchanged online (Holbrey \& Coulson, 2013).

In this study, all participants were independent to decide about their participation, and this may have led to recruitment of women who were better informed about PCOS, thus undermining the limitations discussed in the previous sections. The participants in this study were diverse in terms of age and the level of education. Approximately $73 \%$ of respondents in this study were between the ages 18 and 38years representing the common age group diagnosed with PCOS. 
However, the basic physiological knowledge about reproductive system was limited among 50 to $70 \%$ of participants. The only known information the majority (52.1\%) knew was that PCOS is associated with multiple follicles, and it can be observed that almost half of participants doesn't know this information. Information about important symptoms and signs associated with PCOS such as oligo-anovulation, infertility, hyperandrogenism (with acne and hirsutism) and hyperinsulinemia was limited in approximately 60 to $77 \%$ of participants. Usually obesity is found in more than $50 \%$ of patients diagnosed with PCOS, which is an important complication associated with PCOS (Ollila et al., 2016). However, this important information about obesity and its association with increasing levels of free testosterone was only known to $56.3 \%$ of the participants. It is one of the important information associated with the disease, as this association can aggravate the clinical presentation of the disease in the form of clinical hyperandrogenism and anovulation (Sedighi et al., 2014).

Metabolic syndrome and its association with PCOS is important information that should be known to patients. But about two thirds of participants are unaware of the complications that would arise with this association. Suboptimal knowledge about important long-term complications was not particular to this study but various studies demonstrated similar results (Moran et al., 2010; Tomlinson, Letherby, Pinkney, Millward, \& Stenhouse, 2013). This is potentially concerning and important observation in this study that participants with PCOS did not perceive complications associated with the association of PCOS and metabolic syndrome (Cardiovascular disease, type $2 \mathrm{DM}$ and Hypercholesterolemia) and its long-term effect on patients health.

Lifestyle change of obese women with PCOS is the first line approach in their self-management that helps in normalizing androgen level and improves ovulation. A weight loss of $5 \%$ to $10 \%$ can have significant clinical impacts on psychological, reproductive and metabolic features of the disease (H. Teede et al., 2010). Exercise can help to improve the condition of women diagnosed with PCOS in two ways: firstly in reducing insulin resistance and secondly by decreasing body fat, which is the storage medium for estrogen and steroid hormones (Sedighi et al., 2014). The knowledge of life style modification with diet and exercise as a self-management approach to decrease weight and to minimize the complications was known to most of the participants. The knowledge of self-management approaches is one of the important factor concerning the women with PCOS, as it can minimize their immediate and long term health concerns and achieve high satisfaction levels with health care (Colwell et al., 2010).

Recent meta-analysis by Naderpoor et al. suggested that metformin medication with life style modification can assist in weight loss management and menstrual cycle among the PCOS patients (Naderpoor et al., 2015). Metformin medication among obese PCOS patients can minimize the risk of developing type 2 DM (Ramachandran et al., 2006). However, the knowledge of pharmacological management of PCOS using oral contraceptive pills to control high level of testosterone was not known to $52.5 \%$ of the participants and metformin to control hyperinsulinemia was not known to $71.4 \%$ of the participants.

From the results collected and analyzed in this study, it can be concluded that there is minimal awareness about signs, symptoms, complications and management approaches of PCOS in more than $60 \%$ of the motivated sample population. It is observed and suggested that the perception of long-term metabolic effects of PCOS on the health of affected individual needs to be optimized. Information and source of information is very crucial to patient with PCOS for better understanding of the disease, complications associated with it, and to participate actively in their disease self-management. It is also suggested that, internet as a source can be considered as one of the best tools with regulated information by healthcare authorities for educating women with PCOS.

However, it should be acknowledged that there are some limitations in this study, as it based mainly on self-motivated participants who are familiar with the disease and Internet use. This can lead to the recruitment of well-informed participants with respect to the PCOS and its complications. Another limitation of the study is that it may be unclear whether or not some of the participants are properly diagnosed with PCOS, which could inflate the sample. This could influence the results, as participants may not be representing the true patients diagnosed with PCOS.

\section{Acknowledgements}

The authors would like to acknowledge financial support for this work, from the Deanship of Scientific Research (DSR), university of Tabuk, Tabuk, Saudi Arabia, under grant no. S-0098-1437.

\section{Competing Interests Statement}

The authors declare that thers is no competing or potential conflicts of interest regarding the publication of this paper. 


\section{References}

Avery, J. C., \& Braunack-Mayer, A. J. (2007). The information needs of women diagnosed with Polycystic Ovarian Syndrome--implications for treatment and health outcomes. BMC Womens Health, 7, 9. https://doi.org/10.1186/1472-6874-7-9

Broekmans, F. J., Knauff, E. A., Valkenburg, O., Laven, J. S., Eijkemans, M. J., \& Fauser, B. C. (2006). PCOS according to the Rotterdam consensus criteria: Change in prevalence among WHO-II anovulation and $\begin{array}{lllll}\text { association with metabolic factors. } & B J O G, & 113(10), & 1210-1217 .\end{array}$ https://doi.org/10.1111/j.1471-0528.2006.01008.x

Colwell, K., Lujan, M. E., Lawson, K. L., Pierson, R. A., \& Chizen, D. R. (2010). Women's perceptions of polycystic ovary syndrome following participation in a clinical research study: implications for knowledge, feelings, and daily health practices. $J$ Obstet Gynaecol Can, 32(5), 453-459. https://doi.org/10.1016/S1701-2163(16)34499-1

Holbrey, S., \& Coulson, N. S. (2013). A qualitative investigation of the impact of peer to peer online support for women living with polycystic ovary syndrome. BMC Womens Health, 13, 51. https://doi.org/10.1186/1472-6874-13-51

Kitzinger, C., \& Willmott, J. (2002). 'The thief of womanhood': women's experience of polycystic ovarian syndrome. Soc Sci Med, 54(3), 349-361. https://doi.org/10.1016/S0277-9536(01)00034-X

Lobo, R. A. (2001). Priorities in polycystic ovary syndrome. Med J Aust, 174(11), 554-555.

Memish, Z. A., El Bcheraoui, C., Tuffaha, M., Robinson, M., Daoud, F., Jaber, S., . . Al Rabeeah, A. A. (2014). Obesity and associated factors--Kingdom of Saudi Arabia, 2013. Prev Chronic Dis, 11, E174. https://doi.org/10.5888/pcd11.140236

Moran, L., Gibson-Helm, M., Teede, H., \& Deeks, A. (2010). Polycystic ovary syndrome: a biopsychosocial understanding in young women to improve knowledge and treatment options. J Psychosom Obstet Gynaecol, 31(1), 24-31. https://doi.org/10.3109/01674820903477593

Naderpoor, N., Shorakae, S., de Courten, B., Misso, M. L., Moran, L. J., \& Teede, H. J. (2015). Metformin and lifestyle modification in polycystic ovary syndrome: systematic review and meta-analysis. Hum Reprod Update, 21(5), 560-574. https://doi.org/10.1093/humupd/dmv025

Norman, R. J., Wu, R., \& Stankiewicz, M. T. (2004). 4: Polycystic ovary syndrome. Med J Aust, 180(3), 132-137.

Ollila, M. M., Piltonen, T., Puukka, K., Ruokonen, A., Jarvelin, M. R., Tapanainen, J. S., . . Morin-Papunen, L. (2016). Weight Gain and Dyslipidemia in Early Adulthood Associate With Polycystic Ovary Syndrome: Prospective Cohort Study. J Clin Endocrinol Metab, 101(2), 739-747. https://doi.org/10.1210/jc.2015-3543

Pasquali, R., \& Gambineri, A. (2015). A comprehensive approach in diagnosing the polycystic ovary syndrome. Womens Health (Lond), 11(4), 501-512. https://doi.org/10.2217/whe.15.13

Ramachandran, A., Snehalatha, C., Mary, S., Mukesh, B., Bhaskar, A. D., Vijay, V., \& Indian Diabetes Prevention, P. (2006). The Indian Diabetes Prevention Programme shows that lifestyle modification and metformin prevent type 2 diabetes in Asian Indian subjects with impaired glucose tolerance (IDPP-1). Diabetologia, 49(2), 289-297. https://doi.org/10.1007/s00125-005-0097-z

Sedighi, S., Amir Ali Akbari, S., Afrakhteh, M., Esteki, T., Alavi Majd, H., \& Mahmoodi, Z. (2014). Comparison of lifestyle in women with polycystic ovary syndrome and healthy women. Glob J Health Sci, 7(1), 228-234. https://doi.org/10.5539/gjhs.v7n1p228

Stankiewicz, M., \& Norman, R. (2006). Diagnosis and management of polycystic ovary syndrome: a practical guide. Drugs, 66(7), 903-912. https://doi.org/10.2165/00003495-200666070-00002

Teede, H., Deeks, A., \& Moran, L. (2010). Polycystic ovary syndrome: a complex condition with psychological, reproductive and metabolic manifestations that impacts on health across the lifespan. BMC Med, 8, 41 . https://doi.org/10.1186/1741-7015-8-41

Teede, H. J., Misso, M. L., Deeks, A. A., Moran, L. J., Stuckey, B. G., Wong, J. L., . . Guideline Development, G. (2011). Assessment and management of polycystic ovary syndrome: summary of an evidence-based guideline. Med J Aust, 195(6), S65-112. https://doi.org/10.5694/mja11.10915

Thornton, E. C., Von Wald, T., \& Hansen, K. (2015). Polycystic Ovarian Syndrome: A Primer. S D Med, 68(6), 257-261. 
Tomlinson, J., Letherby, G., Pinkney, J., Millward, A., \& Stenhouse, E. (2013). Raising awareness of polycystic ovary syndrome. Nurs Stand, 27(40), 35-39. https://doi.org/10.7748/ns2013.06.27.40.35.e7536

\section{Copyrights}

Copyright for this article is retained by the author(s), with first publication rights granted to the journal.

This is an open-access article distributed under the terms and conditions of the Creative Commons Attribution license (http://creativecommons.org/licenses/by/4.0/). 